EXPERIMENTAL STUDY

\title{
Interaction between malnutrition and ovarian hormones on the systemic IGF-I axis
}

\author{
Luis Goya ${ }^{1}$, Luis Miguel García-Segura ${ }^{2}$, Sonia Ramos $^{1}$, Ana María Pascual-Leone ${ }^{1}$, Jesús Argente, \\ María Angeles Martín ${ }^{1}$ and Julie A Chowen \\ Department of Endocrinology, Laboratory of Research, Universidad Autónoma, Hospital Niño Jesús, ${ }^{1}$ Institute of Biochemistry, \\ CSIC-Universidad Complutense and ${ }^{2}$ Instituto Cajal, CSIC, Madrid, Spain \\ (Correspondence should be addressed to J Argente, Department of Endocrinology, Hospital Universitario Infantil Niño Jesús, Avenida Menéndez Pelayo 65 , \\ 28009 Madrid, Spain; Email: argentefen@terra.es)
}

\begin{abstract}
Objective: In malnutrition both the GH-IGF and reproductive axes are greatly affected. Because the actions of IGF and sex steroids are inter-dependent in many tissues, we have examined how ovariectomy modulates the response of the systemic IGF system to undernutrition.

Design and methods: Peripubertal (30 days of age) female rats were either sham operated or ovariectomized. Five days later half of each group was submitted to a protein-caloric restriction diet. All rats were killed at 60 days of age.

Results: Growth was decreased in all rats submitted to calorie restriction and this was consistent with a decrease in circulating IGF-I concentrations and liver IGF-I mRNA expression. While in normally fed rats ovariectomy had no significant effect on serum IGF-I concentrations, ovariectomized and underfed rats had significantly higher levels than intact underfed rats. In undernourished rats, serum IGF-binding proteins (IGFBP)-1, -2 and -3 concentrations were significantly reduced and this was not modified by ovariectomy. In contrast, liver mRNA concentrations of IGFBP-1 and -2 were increased and IGFBP-3 unchanged in intact undernourished animals, suggesting that undernutrition could be affecting the proteolysis of these binding proteins, and this response was significantly modulated by ovariectomy.

Conclusion: These results indicate that the presence of circulating ovarian hormones significantly affects the response of the IGF system to undernutrition.

European Journal of Endocrinology 147 417-424
\end{abstract}

\section{Introduction}

In clinical situations of undernutrition, including anorexia nervosa, poorly controlled diabetes mellitus and celiac disease, as well as in experimentally induced undernutrition, the insulin-like growth factor (IGF) axis is markedly altered (1-11). Serum IGF-I concentrations, as well as those of some IGF-binding proteins (IGFBPs), are regulated by growth hormone (GH). However, in malnutrition circulating IGF-I concentrations can be dramatically reduced even when GH secretion is increased or unaltered (2). Hence, in extreme cases of malnutrition the role of $\mathrm{GH}$ as the primary regulator of circulating IGF-I concentrations is diminished, but what factors become important in the control of the IGF-I system is less clear.

In severe undernutrition the reproductive axis is also suppressed, with markedly reduced levels of circulating sex steroids $(12,13)$. Indeed, one of the diagnostic features of anorexia nervosa is amenorrhea in post-pubertal females (14). After nutritional therapy and substantial weight recuperation, or even attainment of a normal body mass index, menstruation may not be spontaneous and estrogen therapy may be required. Likewise, after adequate nutrition and significant weight gain circulating IGF-I and IGFBP concentrations do not immediately return to normal $(2,7)$, suggesting a possible interaction of these two systems.

Sex steroids and IGF-I interact at different levels in a variety of tissues and sufficient levels of both hormones may be necessary for the normal physiological functioning of some systems (15-21). In some tissues IGF-I modulates estrogen receptor levels and estrogens regulate the production of IGF-I, its receptors and the IGFBPs $(17,19-21)$. In addition, synergistic effects and cross-reactivity, with one factor activating or requiring the presence of receptors of the other, have been demonstrated in certain cell types $(16,18)$. Sex steroids and IGF-I have also been reported to have 
numerous points of interaction in their intracellular signaling mechanisms in many tissues $(5,22)$. Hence, the physiological response of one system may depend, at least in part, upon the condition or hormone levels of the other system.

Most studies analyzing the IGF-I system in undernutrition have been done in adult intact animals. Since sex steroid levels are also modulated in undernutrition, we hypothesized that this may be involved with the changes occurring in the IGF system. In this study we have examined whether the absence of ovarian hormones modulates the known effects of undernutrition on the circulating IGF-I system.

\section{Materials and methods}

\section{Animals}

Female Wistar rats, bred in our animal facilities and housed under controlled temperature and an artificial $12 \mathrm{~h}$ light: $12 \mathrm{~h}$ darkness cycle, were used in this study. Rats were freely fed a standard laboratory diet (19 g protein, $56 \mathrm{~g}$ carbohydrate, $3.5 \mathrm{~g}$ lipid, $4.5 \mathrm{~g}$ cellulose/100 g, plus salt and vitamin mixtures) and water. Trunk blood was harvested after decapitation and sera stored at $-80{ }^{\circ} \mathrm{C}$ until assayed. Livers were frozen in liquid nitrogen.

European Community regulations for the use of animals for experimental models and other scientific purposes were followed. In addition, all experiments were conducted in accordance with the principles and procedures outlined in the National Institutes of Health (NIH, Bethesda, MD, USA) guide for the care and use of experimental animals.

\section{Experimental groups}

On postnatal day 30, half of the rats were ovariectomized and half sham operated. Five days later these two groups were divided into two subgroups. One subgroup was fed normally and the other submitted to a calorie-restricted diet that corresponded to approximately a $65 \%$ reduction in intake. All rats were killed on postnatal day 60. The groups are represented in Table 1.

Table 1 Experimental groups. OVX = ovariectomized. All animals were killed at 60 days of age.

\begin{tabular}{lcc}
\hline Group & Treatment (day 30) & Nutrition (starting day 35) \\
\hline F & Sham & Fed normally \\
OVX+F & OVX & Fed normally \\
$U$ & Sham & Undernourished \\
OVX+U & OVX & Undernourished \\
\hline
\end{tabular}

\section{Serum IGF-I assay}

The method for IGF-I RIA has been previously described (23). Before IGF determination serum IGFBPs were removed by standard acid-gel filtration. Standards and samples were assayed in triplicate. The intra- and inter-assay coefficients of variation were 8.0 and $12.4 \%$ respectively. Interference of IGF-II in the assay was $11.7 \%$ and data were corrected accordingly.

\section{Western ligand blotting}

Western ligand blots were performed as previously described $(5,23)$. Briefly, sera were diluted in sample buffer (Tris-HCl, $0.625 \mathrm{~mol} / \mathrm{l}, \mathrm{pH} 6.8 ; 10 \% \quad(\mathrm{v} / \mathrm{v})$ glycerol; $2 \%$ sDs and $0.0125 \%$ bromophenol blue) and $2.5 \mu \mathrm{l}$ serum were submitted to SDS-PAGE under non-reducing conditions (to prevent denaturation of IGFBPs) on a $10 \%$ polyacrylamide gel. After electrotransfer to nitrocellulose, the membranes were incubated with ${ }^{125}$ I-labeled IGF-II $\left(10^{6}\right.$ c.p.m. $)$ for $20 \mathrm{~h}$ at $4^{\circ} \mathrm{C}$ and autoradiographed against Hyperfilm MP between intensifier screens at $-70{ }^{\circ} \mathrm{C}$. Autoradiographs were quantified by two-dimensional densitometry using a Personal Densitometer (Molecular Dynamics, Sunnydale, CA, USA). $\mathrm{Na}^{125} \mathrm{I}$ and the Hyperfilm MP were purchased from Amersham (Amersham Ibérica SA, Madrid, Spain).

\section{Preparation of RNA}

Total RNA was prepared by homogenization of livers in guanidinium thiocyanate as originally described (24). Samples were electrophoresed through 1\% agarose$2.2 \mathrm{~mol} / \mathrm{l}$ formaldehyde gels and stained with ethidium bromide in order to visualize the $28 \mathrm{~S}$ and $18 \mathrm{~S}$ ribosomal RNA and confirm the integrity of the RNA and normalize the quantity of RNA in the different lanes.

\section{Riboprobes}

Rat IGF-I and IGFBP-1, -2 and -3 cDNAs were kindly provided by Drs D T Roberts and D LeRoith (NIH). Rat IGF-I cDNA, ligated into a pGEM-3 plasmid, was linearized with HindIII and an antisense riboprobe was produced by using T7 RNA polymerase. Use of this riboprobe resulted in two protected fragments of 224 (Ia) and 386 (Ib) bases. The rat IGFBP-1 cDNA, ligated into a pGEM-3 plasmid, was linearized with HindIII and incubated with T7 RNA polymerase to generate an antisense riboprobe that protected two fragments of 300 and 700 bases. Rat IGFBP-2 cDNA, ligated into a pGEM-4Z plasmid (Promega Biotech, Madison, WI, USA), was linearized with HindIII and incubated with SP6 RNA polymerase to generate a 550 base antisense riboprobe devoid of pGEM-4Z complementary sequences. The rat IGFBP-3 cDNA, ligated into a pGEM-4Z plasmid, was linearized with 
AccI and transcribed with T7 RNA polymerase to generate a 343 base antisense riboprobe. The above riboprobes were synthesized with $\left[{ }^{32} \mathrm{P}\right] \mathrm{UTP}$ (Nuclear Ibérica SA, Madrid, Spain). The riboprobe Gemini II Core System (Promega) was used for the generation of the RNA probes.

\section{Solution hybridization/RNAse protection assay}

Solution hybridization/RNase protection assays were performed as previously described $(5,25)$. Autoradiography was performed at $-70{ }^{\circ} \mathrm{C}$ against Hyperfilm MP between intensifying screens. Bands representing protected probe fragments were quantified using a Molecular Dynamics scanning densitometer and accompanying software. RNase A and T1 were purchased from Boehringer Mannheim.

\section{Statistical analysis}

All data are presented as means \pm S.D. Statistical comparisons were performed by one-way ANOVA, followed by the protected least significant difference test.

\section{Results}

\section{Body weight}

As shown in Fig. 1, undernourished rats gained weight at a significantly lower rate than normally fed rats. Ovariectomy increased weight gain in normally fed rats, but this was not significant. However, ovariectomy significantly decreased weight gain in undernourished animals.

\section{Serum IGF-I concentration (RIA)}

In intact rats, undernutrition caused a significant decrease in serum IGF-I concentrations (Fig. 2).

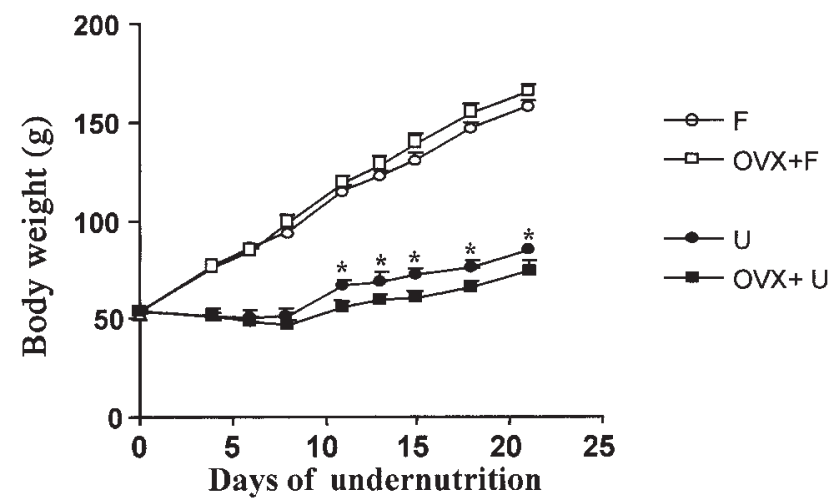

Figure 1 Mean \pm S.D. body weights of rats throughout the study period. F, fed normally; OVX, ovariectomized (30 days of age); $\mathrm{U}$, undernourished (beginning at 35 days of age). ${ }^{*}$ Significantly different from all other groups, $n=6$.
Serum IGF-I concentrations were not affected by ovariectomy in normally fed rats. However, undernourished ovariectomized rats had significantly higher serum IGF-I concentrations compared with intact undernourished rats (Fig. 2).

\section{Liver IGF-I mRNA concentration (RNase protection assay)}

Liver IGF-I mRNA concentrations were significantly decreased by both undernutrition and ovariectomy, but these effects were not additive (Fig. 3).

\section{Serum IGFBP-1, -2 and -3 concentrations (Western blot)}

Western ligand blots showed that the $30 \mathrm{kDa}$ complex of IGFBP-1 and -2 was decreased in undernourished vs fed rats and ovariectomy had no effect (Fig. 4).

Serum IGFBP-3 concentrations were also decreased in undernourished rats as compared with fed rats and ovariectomy had no effect (Fig. 4).

\section{Liver IGFBP-1, -2 and -3 mRNA concentrations (RNase protection assay)}

In intact rats, liver IGFBP-1 mRNA concentrations increased significantly as a result of undernutrition (fed normally vs undernourished) and ovariectomy had no effect (fed normally vs ovariectomized and fed normally) (Fig. 5). In contrast, in ovariectomized animals undernourishment had no effect on IGFBP-1 mRNA concentrations (ovariectomized and fed normally vs ovariectomized and undernourished).

Liver IGFBP-2 mRNA concentrations were markedly higher in undernourished rats compared with fed rats.

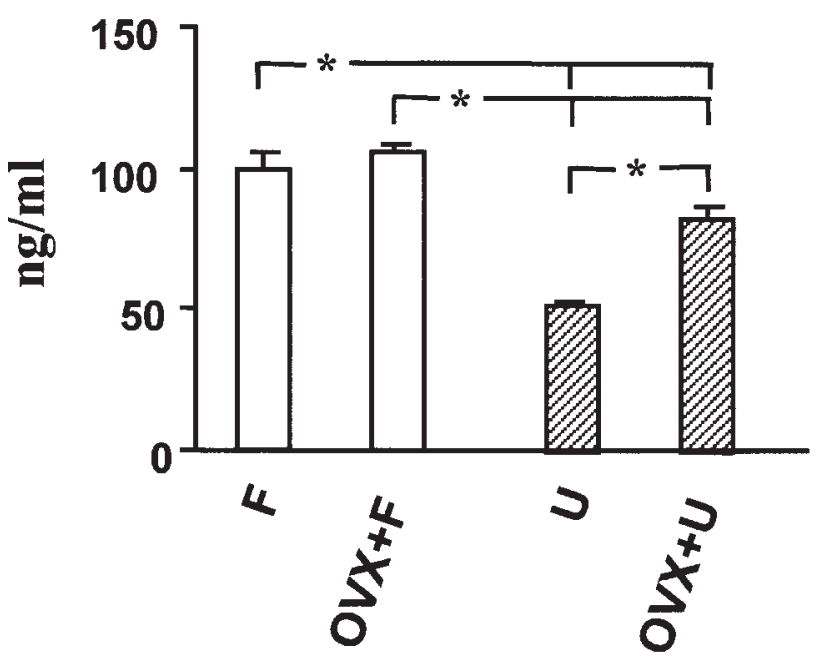

Figure 2 Mean \pm S.D. circulating IGF-I levels as measured by RIA. $\mathrm{F}$, fed normally; OVX, ovariectomized; $\mathrm{U}$, undernourished. ${ }^{*} P<0.05$, ANOVA, $n=6$. 


\section{IGF-I}
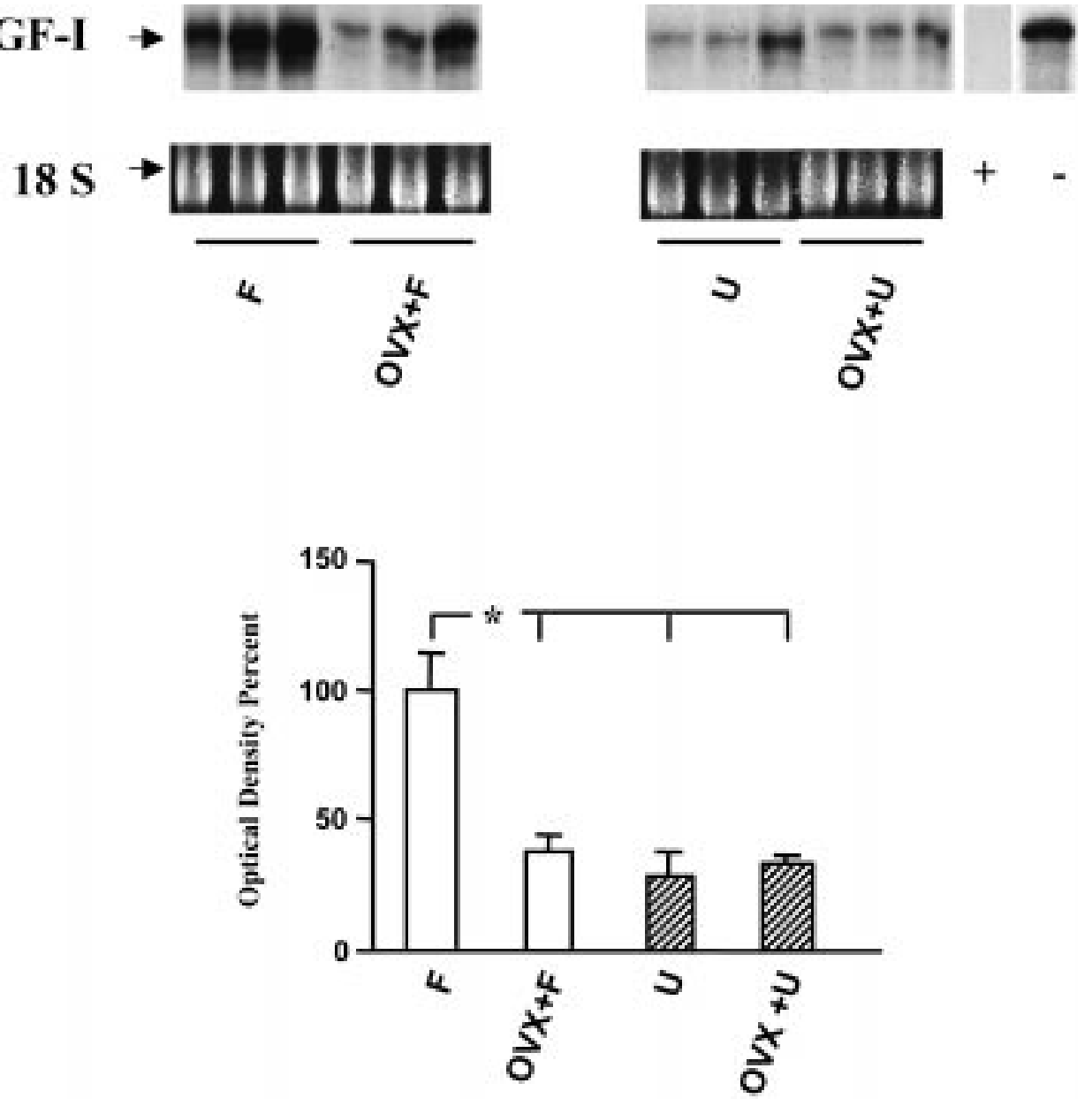

Figure 3 Mean \pm S.D. liver IGF-I mRNA levels as measured by RNase protection assay. F, fed normally; OVX, ovariectomized; $\mathrm{U}$, undernourished. ${ }^{*} P<0.05$, ANOVA, $n=6$.

In normally fed rats, ovariectomy had no effect; however, undernourished ovariectomized rats had significantly lower concentrations than intact undernourished rats (Fig. 5).

Ovariectomy evoked a decrease in liver IGFBP-3 mRNA concentrations in both fed and undernourished rats (Fig. 5). Liver IGFBP-3 mRNA concentrations were not altered by undernutrition in either intact or ovariectomized rats.

\section{Discussion}

Linear growth is directly controlled by $\mathrm{GH}$, in part via IGF-I $(26,27)$, with other factors such as nutrition and the hormonal environment playing modulatory roles $(10,28)$. To the best of our knowledge, the effect of malnutrition on the IGF-I system during puberty has not been reported previously. Since pubertal transition is coincident with normal changes in IGF-I, IGFBPs and sex steroid levels $(29,30)$, the response to undernutrition could be distinct at this developmental stage.

Undernutrition, or poor nutrition, inhibits growth in the laboratory rat $(5,10,11)$ and is one of the major causes of short stature in humans $(31,32)$. In agreement, we now show that undernutrition of peripubertal rats significantly reduced body weight, which at this age is directly proportional to linear growth (33). Circulating IGF-I and liver IGF-I mRNA levels were significantly reduced, as reported in adults $(5,6,8,9$, 25 ), and this could explain the decreased longitudinal growth.

Circulating IGFBP levels are also modulated by malnutrition and catabolic states $(1-5,8,9,25)$. Adult rats on a calorie-restricted diet have increased IGFBP-1 and -2 and decreased IGFBP-3 levels, as do anorexia nervosa patients (2). In poorly controlled diabetic rats, circulating IGFBP-1 is increased and IGFBP-3 decreased (3), similar to what is observed in diabetic humans (1). We found circulating IGFBP-3 concentrations to be reduced, but IGFBP-1 and -2 


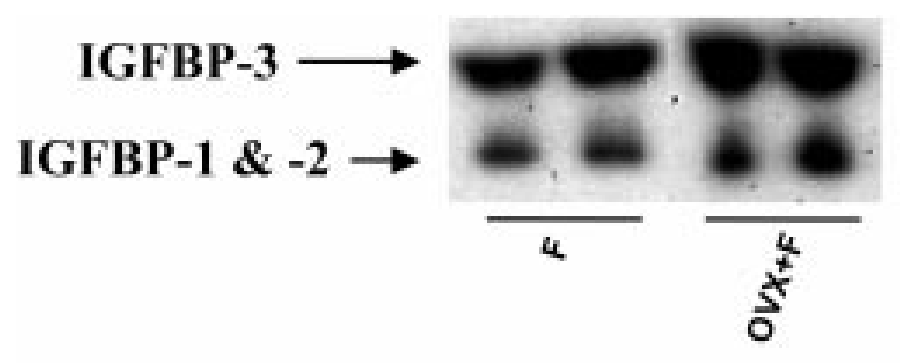

IGFBP-1 \& -2

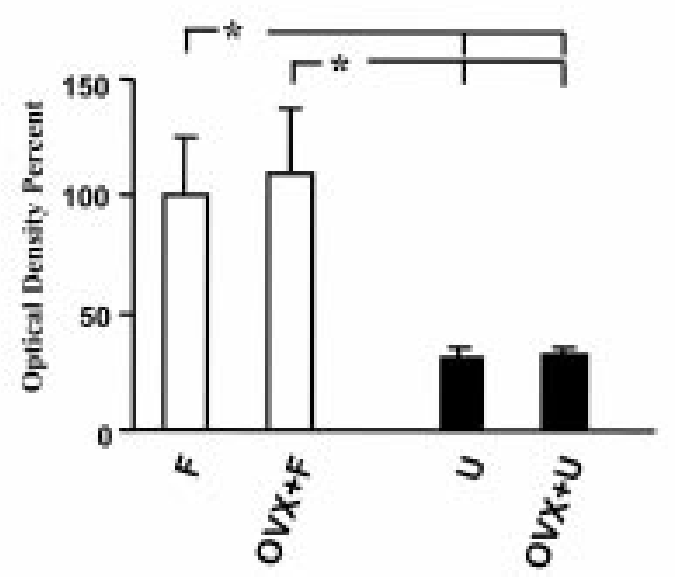

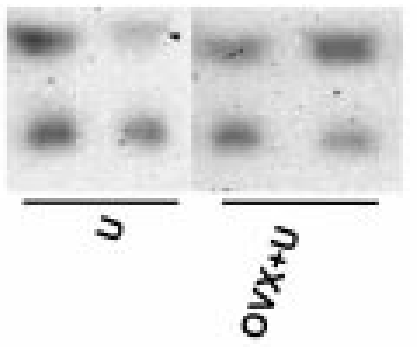

IGFBP-3

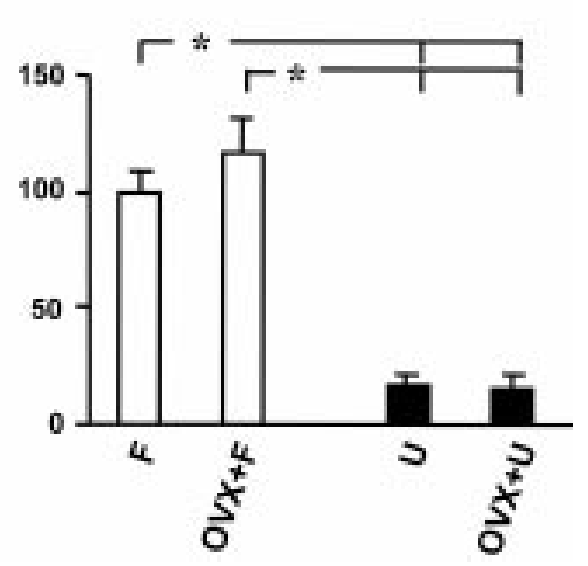

Figure 4 Mean \pm S.D. circulating IGFBP-1, -2 and -3 levels as measured by Western blot analysis. F, fed normally; OVX, ovariectomized; $\mathrm{U}$, undernourished. ${ }^{*} P<0.05$, ANOVA, $n=6$.

were also significantly decreased. This difference could be due to the age-dependent response of IGFBPs to malnutrition $(5,34)$.

In contrast to the decrease in circulating IGFBP levels, in undernourished intact rats, liver mRNA levels for IGFBP-1 and -2 were increased with no change in IGFBP-3. A similar discrepancy was reported where protein restriction reduced plasma IGFBP-3 and -4 levels, but liver mRNA levels did not change (4). This discordance between changes in protein and mRNA concentrations could be due to undernutrition increasing IGFBP clearance or protease activity (6). Alternatively, the liver may not be the main source of the changes reported here, as other tissues also produce IGFBPs (26).

The ovary inhibits systemic growth, at least partially due to its production of estrogens $(19,28)$. Although estrogens are highly effective in blocking the sequelae of $\mathrm{GH}$ overproduction in acromegaly, it has been shown that they actually stimulate GH secretion in humans (35). Hence, how can estrogens slow growth while increasing GH? In effect, estrogen therapy causes a rapid fall in IGF-I, but not in GH (36), although this depends on the estrogen dose used (37). Estrogens stimulate the closing of the epiphyses, as demonstrated clearly by patients with mutations in either the estrogen receptor- $\alpha$ or aromatase genes. Indeed, these patients continued to grow even into adulthood, due to the lack of estrogen effects and epiphyseal closure (for review see 38).

In most animal studies ovariectomy is reported to stimulate both growth and circulating IGF-I levels $(19,20,28,39-41)$, which is in contrast to the lack of effect shown here. In our studies rats were castrated before puberty, so they had not been exposed to normal post-pubertal levels of ovarian hormones. Therefore, their response to later hormonal manipulations may differ from that of adult animals. This may also explain why we found no effect of ovariectomy on serum IGFBP-1, -2 or -3 concentrations, while other authors report changes $(4,41)$.

Ovariectomy decreased liver IGF mRNA levels, but not circulating IGF-I levels, suggesting that modulation of transduction, protein processing or clearance may also occur. On the other hand, although under normal circumstances the liver is the main source of circulating IGF-I, other organs produce substantial amounts and could influence plasma IGF-I levels. Indeed, not all tissues have the same response to ovarian hormone manipulations, with some even 

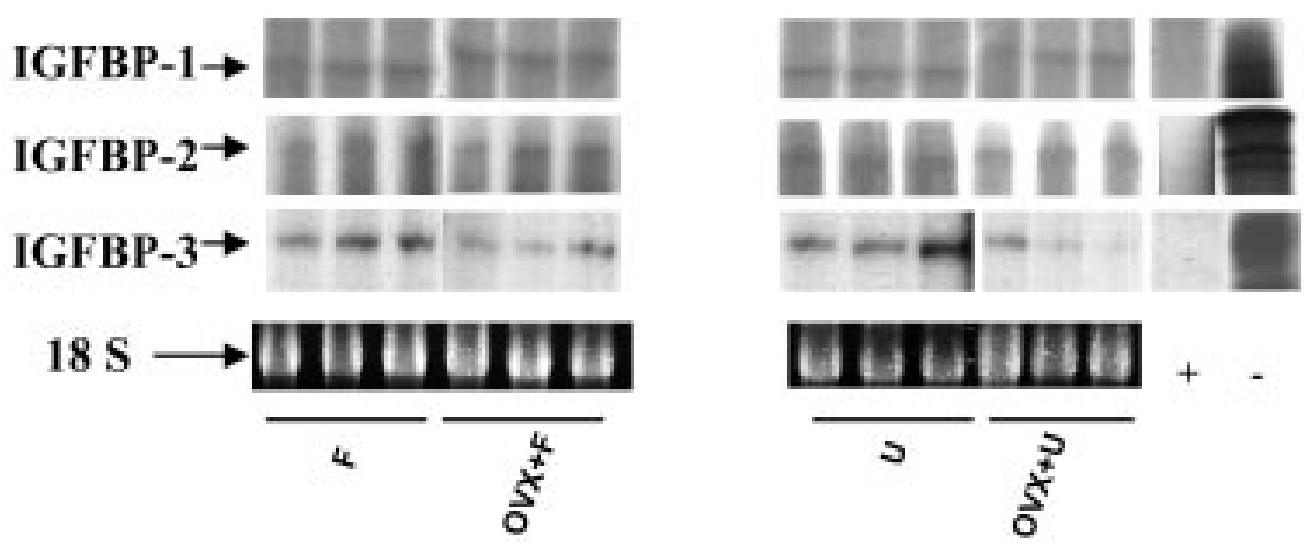

IGFBP-1 mRNA

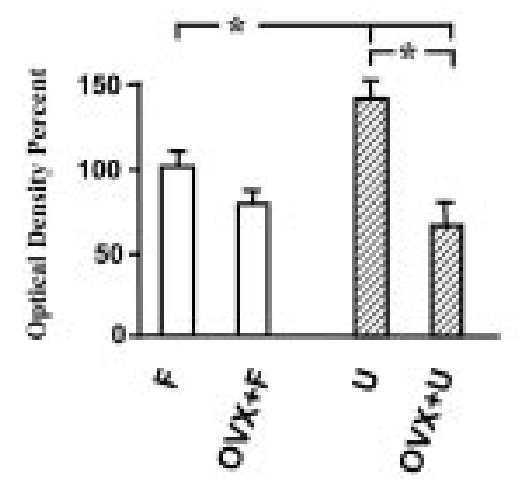

IGFBP-2 mRNA

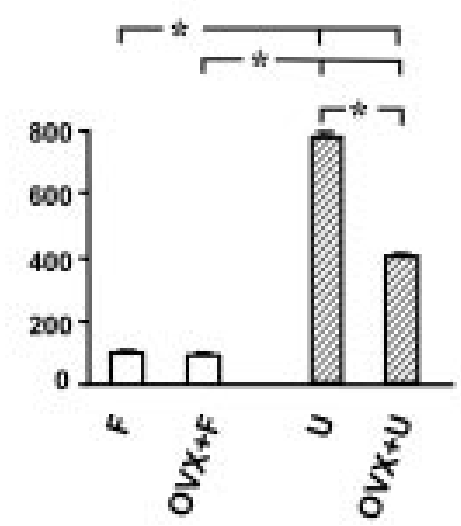

IGFBP-3 mRNA

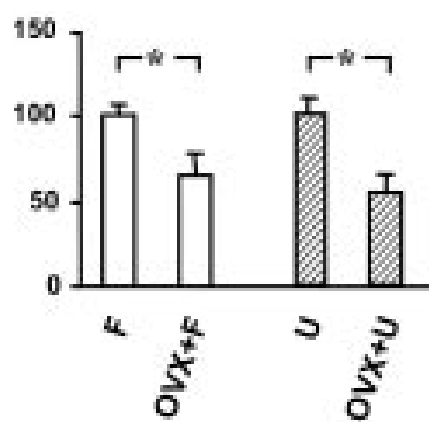

Figure 5 Mean \pm S.D. liver IGFBP-1, -2 and -3 mRNA levels as measured by RNase protection assay. F, fed normally; OVX, ovariectomized; $\mathrm{U}$, undernourished. ${ }^{*} P<0.05$, ANOVA, $n=6$.

increasing IGF-I expression in response to ovariectomy $(42,43)$.

Sex steroids modulate the IGF-GH axis at the level of the hypothalamus $(33,44,45)$, pituitary $(46,47)$ and target tissues $(19,42,43)$. In addition, the response of some cells to GH or IGF-I depends on the presence of sex steroids and vice versa and sex steroid actions on the GH-IGF-I axis are also age-dependent (48). In rats, pubertal growth, which occurs between approximately 35 and 45 days of age $(28,33)$, takes place even in the absence of the gonads, although to a lesser degree (33), suggesting that sex steroids are not the only factor involved in this phenomenon. Furthermore, the interaction between sex steroids and the GH-IGF-I axis is different during puberty compared with other developmental periods (48).

The effect of undernutrition on growth was even more pronounced in ovariectomized rats, which grew significantly less than underfed intact animals even though their circulating IGF-I levels were higher. Fisher and colleagues (39) reported that circulating IGF-I levels increased in ovariectomized rats, but were not affected in ovariectomized and undernourished animals. In addition, although circulating levels of IGFBPs remained decreased in undernourished ovariectomized rats, their liver mRNA levels tended to normalize. In effect, there appears to be a complex interaction between the effects of ovarian hormones and malnutrition on the growth axis. Our results suggest that ovarian hormones may amplify some of the effects of malnutrition on this system. However, systemic growth itself was less suppressed in intact animals, indicating that the end result of these changes is less affected in the presence of ovarian hormones.

Under conditions of malnutrition the protective behaviour adopted by the body must be taken into consideration. Although the mechanisms of this phenomenon are not well understood, it is accepted that the organism favors vital functions and organs, such as the nervous or cardiac systems, over non-vital functions (e.g. reproduction or growth) in situations of extreme stress. Undernutrition results in a reduction in longitudinal growth and a 'shut-down' of the reproductive axis and, as shown here, removal of ovarian 
hormones exaggerates the effect on growth, suggesting that these two effects are intertwined. Furthermore, although removal of ovarian hormones further decreases longitudinal growth, part of the IGF axis tends to normalize, suggesting that these factors may be available for other important functions.

In conclusion, these results emphasize the complex interaction between the GH-IGF axis and gonadal steroids, emphasizing the possible age-dependent aspects. Indeed, the effects of malnutrition on systemic growth may be distinct depending on the pubertal stage of the subject. It is logical that during periods of more rapid growth, such as puberty, any assault on this system could have a more dramatic effect. However, the adaptive capabilities of the organism may function to lessen the possible detrimental effects, becoming more efficient with the limited resources available.

\section{Acknowledgements}

This work was supported by grants from the Comunidad de Madrid (CAM 085/0009), Fondo de Investigación Sanitarias (FIS 00/0222) and the Fundación Endocrinología y Nutrición.

\section{References}

1 Muñoz MT, Barrios V, Pozo J \& Argente J. Insulin-like growth factor I, its binding proteins 1 and 3, and growth hormonebinding protein in children and adolescents with insulindependent diabetes mellitus: clinical implications. Pediatric Research $199639992-998$.

2 Argente J, Caballo N, Barrios V, Muñoz MT, Pozo J, Chowen JA et al. Multiple endocrine abnormalities of the growth hormone and insulin-like growth factor axis in patients with anorexia nervosa: effect of short-and long-term recuperation. Journal of Clinical Endocrinology and Metabolism 199782 2084-2092.

3 Busiguina S, Chowen JA, Argente J \& Torres-Aleman I. Specific alterations of the insulin-like growth factor I system in the cerebellum of diabetic rats. Endocrinology $19961374980-4987$.

4 Takenaka A, Mori M, Yamada S, Ohgane J, Takahashi S \& Noguchi T. Nutritional regulation of gene expression of insulinlike growth factor-binding proteins and the acid-labile subunit in various tissues of rats. Journal of Endocrinology $1996 \mathbf{1 5 0}$ $33-41$.

5 Rivero F, Goya L, Aláez C \& Pascual-Leone AM. Effects of undernutrition and diabetes on serum and liver mRNA expression of IGFs and their binding proteins during rat development. Journal of Endocrinology 1995145 427-440.

6 Ketelslegers JM, Maiter D, Maes M, Underwood LE \& Thissen JP. Nutritional regulation of insulin-like growth factor-I. Metabolism 199544 (Suppl 4) 50-57.

7 Hernández M, Argente J, Navarro A, Caballo N, Barrios V, Hervas F et al. Growth in malnutrition related to gastrointestinal diseases: coeliac disease. Hormone Research 199238 (Suppl 1) 79-84.

8 Estivariz CF \& Ziegler TR. Nutrition and the insulin-like growth factor system. Endocrine 1997 7 65-71.

9 Goya L, Rivero F, Martín MA, Álvarez C, Ramos S, de la Puente A et al. Liver mRNA expression of IGF-I and IGFBPs in adult undernourished diabetic rats. Life Sciences $1999642255-2271$.

10 Underwood LE. Nutritional regulation of IGF-I and IGFBPs. Journal of Pediatric Endocrinology and Metabolism 19969 $303-312$.
11 Underwood LE, Thissen JP, Lemozy S, Ketelslegers JM \& Clemmons DR. Hormonal and nutrition regulation of IGF-I and its binding proteins. Hormone Research $1994 \mathbf{4 2} 145-151$.

12 Van Binsbergen CJ, Coelingh-Bennink HJ, Odink J, Haspels AA \& Koppeschaar HP. A comparative and longitudinal study on endocrine changes related to ovarian function in patients with anorexia nervosa. Journal of Clinical Endocrinology and Metabolism 199071 705-711.

13 Pirke KM, Schweiger U, Lemmel W, Kreig JC \& Berger M. The influence of dieting on the menstrual cycle of healthy young women. Journal of Clinical Endocrinology and Metabolism 1985 $601174-1179$.

14 American Psychiatric Association. Diagnostic and Statistical Manual of Mental Disorders, edn 4. Washington DC: American Psychiatric Association, 1994.

15 García-Segura LM, Cardona-Gómez GP, Chowen JA \& Azcoitia I. Insulin-like growth factor-I receptors and estrogen receptors interact in the promotion of neuronal survival and neuroprotection. Journal of Neurocytology 200029 425-437.

16 Aronica SM \& Katzenellenbogen BS. Stimulation of estrogen receptor-mediated transcription and alteration in the phosphorylation state of the rat uterine estrogen receptor by estrogen, cyclic adenosine monophosphate, and insulin-like growth factor-I. Molecular Endocrinology $19937743-753$.

17 Cardona-Gómez GP, Chowen JA \& García-Segura LM. Estradiol and progesterone regulate the expression of insulin-like growth factor-I receptor and insulin-like growth factor binding protein2 in the hypothalamus of adult female rats. Journal of Neurobiology $200043269-281$.

18 Newton CJ, Buric R, Trapp T, Brockmeier S, Pagotto U \& Stalla GK. The unliganded estrogen receptor (ER) transduces growth factor signals. Journal of Steroid Biochemistry and Molecular Biology 199448 481-486.

19 Borski RJ, Tsai W, DeMott-Friberg R \& Barkan AL. Regulation of somatic growth and the somatotropic axis by gonadal steroids: primary effect on insulin-like growth factor I gene expression and secretion. Endocrinology $19961373253-3259$.

20 Krattenmacher R, Knauthe R, Parczyk K, Walker A, Hilgenfeldt U \& Fritzemeier KH. Estrogen action on hepatic synthesis of angiotensinogen and IGF-I: direct and indirect estrogen effects. Journal of Steroid Biochemistry and Molecular Biology $1994 \mathbf{4 8}$ 207-214.

21 Norstedt G, Levinovitz A \& Eriksson H. Regulation of uterine insulin-like growth factor I mRNA and insulin-like growth factor II mRNA by estrogen in the rat. Acta Endocrinologica $1989120466-472$.

22 Cheng HL \& Feldman EL. Bidirectional regulation of p38 kinase and c-Jun N-terminal protein kinase by insulin-like growth factor-I. Journal of Biological Chemistry $1998 \quad \mathbf{2 7 3}$ $14560-14565$.

23 Rivero F, Goya L \& Pascual-Leone AM. Comparison of extraction methods for insulin-like growth factor-binding proteins prior to measurement of insulin-like growth factor-I in undernourished neonatal and adult rat serum. Journal of Endocrinology 1994 $140257-263$.

24 Chomczynski P \& Sacchi N. Single step method of RNA isolation by acid guanidinium thiocyanate-phenol-chloroform extraction. Annals of Biochemistry 1987162 156-159.

25 Goya L, Rivero F, Martín MA, Arahuetes R, Hernández ER \& Pascual-Leone AM. Effects of refeeding of undernourished and insulin treatment of diabetic neonatal rats on IGF and IGFBP. American Journal of Physiology 1996271 E223-E231.

26 Le Roith D, Bondy C, Yakar S, Liu JL \& Butler A. The somatomedin hypothesis. 2001. Endocrine Reviews 200122 53-74.

27 Butler AA \& Le Roith D. Control of growth by the somatotropic axis: growth hormone and the insulin-like growth factors have related and independent roles. Annual Review of Physiology 2001 63 141-164.

28 Jansson J-O, Edén S \& Isaksson O. Sexual dimorphism in the control of growth hormone secretion. Endocrine Reviews 19856 $128-150$. 
29 Argente J, Barrios V, Pozo J, Muñoz MT \& Hernández M. Normative data for insulin-like growth factors (IGFs), IGF-binding proteins, and growth hormone-binding protein in a healthy Spanish pediatric population: age and sex related changes. Journal of Clinical Endocrinology and Metabolism $199375762-767$.

30 Mauras N, Rogol AD, Haymond MW \& Veldhuis JD. Sex steroids, growth hormone, insulin-like growth factor-I: neuroendocrine and metabolic regulation in puberty. Hormone Research 1996 $4574-80$.

31 Kramer MS. Socioeconomic determinants of intrauterine growth retardation. European Journal of Clinical Nutrition $1998 \mathbf{5 2}$ S29-S32.

32 Darnton-Hill I \& Coyne ET. Feast and famine: socioeconomic disparities in global nutrition and health. Public Health Nutrition $1998123-31$.

33 Chowen JA, Argente J, González-Parra S \& García-Segura LM. Differential effects of the neonatal and adult sex steroid environments on the organization and activation of hypothalamic growth hormone-releasing hormone and somatostatin neurons. Endocrinology $19931332792-2802$.

34 Oster MH, Levin N, Fielder PJ, Robinson IC, Baxter RC \& Cronin MJ. Developmental differences in the IGF-I system response to severe and chronic caloric malnutrition. American Journal of Physiology 1996270 E646-E653.

35 Frantz AG \& Rabkin MT. Effects of estrogen and sex difference on secretion of human growth hormone. Journal of Clinical Endocrinology and Metabolism 196525 1470-1480.

36 Wiedemann E \& Schwartz E. Suppression of growth hormonedependent human serum sulfation factor by estrogen. Journal of Clinical Endocrinology and Metabolism 197234 51-58.

37 Copeland KC. Effects of acute high dose and chronic low dose estrogen on plasma somatomedin-C and growth in patients with Turner's syndrome. Journal of Clinical Endocrinology and Metabolism $1988661278-1282$.

38 Grumbach MM. Estrogen, bone, growth and sex: a sea of changes in conventional wisdom. Journal of Pediatric Endocrinology and Metabolism 200013 1439-1455.

39 Fisher JS, Kohrt WM \& Brown M. Food restriction suppresses muscle growth and augments osteopenia in ovariectomized rats. Journal of Applied Physiology $2000 \mathbf{8 8}$ 265-271.

40 Barengolts EI, Kouznetsova T, Segalene A, Lathon P, Odvina C, Ku SC et al. Effects of progesterone on serum levels of IGF-I and on femur IGF-I mRNA in ovariectomized rats. Journal of Bone and Mineral Research 199611 1406-1412.

41 Kalu DN, Arjmandi BH, Liu CC, Salih MA \& Birnbaum RS. Effects of ovariectomy and estrogen on the serum levels of insulin-like growth factor-I and insulin-like growth factor binding protein-3. Bone and Mineral 199425 135-148.

42 Murphy LJ \& Friesen HG. Differential effects of estrogen and growth hormone on uterine and hepatic insulin-like growth factor I gene expression in the ovariectomized hypophysectomized rat. Endocrinology $1988 \mathbf{1 2 2} 325-332$.

43 Scheidegger KJ, Cenni B, Picard D \& Delafontaine P. Estradiol decreases IGF-I and IGF-I receptor expression in rat aortic smooth muscle cells. Mechanisms for its atheroprotective effects. Journal of Biological Chemistry $200027538921-38928$.

44 Argente J, Chowen-Breed J, Steiner RA \& Clifton DK. Somatostatin messenger RNA in hypothalamic neurons is increased by testosterone through activation of androgen receptors and not by aromatization to estradiol. Neuroendocrinology $1990 \mathbf{5 2}$ 342-349.

45 Zeitler P, Argente J, Chowen-Breed JA, Clifton DK \& Steiner RA. Growth hormone-releasing hormone messenger ribonucleic acid in the hypothalamus of the adult male rat is increased by testosterone. Endocrinology 1990127 1362-1368.

46 González-Parra S, Chowen JA, García-Segura LM \& Argente J. In vivo and in vitro regulation of pituitary transcription factor-1 (Pit-1) by changes in the hormone environment. Neuroendocrinology 199663 3-15.

47 Simard J, Hubert JF, Hosseinzadeh T \& Labrie F. Stimulation of growth hormone release and synthesis by estrogens in rat anterior pituitary cells in culture. Endocrinology 1986119 2004-2011.

48 Wilson ME. Regulation of the growth hormone-insulin-like growth factor axis in developing and adult monkeys is affected by estradiol replacement and supplementation with insulin-like growth factor-I. Journal of Clinical Endocrinology and Metabolism $1998832018-2028$.

Received 26 February 2002

Accepted 12 June 2002 